\title{
CATALOGUES AND THE POETICS OF SYRIAC MANUSCRIPT CULTURES $^{1}$
}

\author{
KRISTIAN S. HEAL \\ BRIGHAM YOUNG UNIVERSITY
}

\begin{abstract}
This essay seeks to demonstrate how the well-made catalogue can contribute to our understanding of the poetics of Syriac manuscript cultures. The recent catalogue of Syriac manuscripts and fragments from the library of Deir al-Surian by Sebastian Brock and Lucas Van Rompay is used as a case study. In aggregating the diverse data points found in the catalogue's thick descriptions a nuanced portrait of the creative dynamics of manuscript cultures emerges. In the process of this study Brock and V an Rompay's catalogue is shown to be a rich repository of cultural information, and a magnificent contribution to our understanding of the Syriac library of Deir al-Surian. An
\end{abstract}

\footnotetext{
${ }^{1}$ Review essay of Sebastian P. Brock and Lucas Van Rompay, Catalogue of the Syriac Manuscripts and Fragments in the Library of Deir al-Surian, $W$ adi alNatrun (Egypt), Orientalia Lovaniensia Analecta 227 (Leuven: Peeters, 2014). Pp. xxii +834 including 318 plates; $€ 105$, hereafter cited as Catalogue. I presented an earlier version of this essay at the Center for Late Ancient Studies Spring symposium, Duke University, March 31 st, 2017. I am grateful for that stimulating context for discussion and thought. I am grateful also to my colleague Carl Griffin for reviewing a near final version of this essay and offering many helpful suggestions and corrections.
} 
appendix provides a topical bibliography of the monastery and Syriac manuscripts of Deir al-Surian.

It is certainly true, as Adam Becker recently stated, that "in the US and Canada one can work in Syriac Studies without engagement with the materiality of our textual sources." Nonetheless, there is a growing interest in precisely this materiality. In the past decade, the critical methodologies of the new historicists, new philologists, and book historians, ${ }^{3}$ methodologies most fully developed in Early English and Medieval studies, have started to influence Oriental manuscript studies, ${ }^{4}$ inspiring scholarship that historicizes single work and multi-text manuscripts, examines more closely the collection and composition of manuscripts, considers traces of authors and readers in manuscript paratexts, and looks at the social context of manuscript and literary production. ${ }^{5}$ Such methods

2 Adam Becker, Review of Françoise Briquel Chatonnet and Muriel Debié, eds., Manuscripta Syriaca. Des sources de première main, Cahiers d'études syriaques 4 (Paris: Geuthner, 2015), Hugoye: Journal of Syriac Studies 20 (2017): 338.

3 See, for example, Robert Darnton, "What is the History of Books?" Daedalus 111 (1982): 65-83; Lee Patterson, Negotiating the Past: The Historical Understanding of Medieval Literature (Madison: University of Wisconsin Press, 1987); H. Aram Veeser, ed., The New Historicism (London: Routledge, 1989); Stephen Nichols, "Philology in a Manuscript Culture," Speculum 65 (1990): 1-10 (introduction to special issue on The New Philology); Bernard Cerquiglini, In Praise of the V ariant: A Critical History of Philology (Baltimore: Johns Hopkins University Press, 1999); Catherine Gallager and Stephen Greenblatt, Practicing New Historicism (Chicago: Chicago University Press, 2000).

${ }^{4}$ Most recently, Liv Ingeborg Lied and Hugo Lundhaug, eds., Snapshots of Evolving Traditions: Jewish and Christian Manuscript Culture, Textual Fluidity, and New Philology (Texte und Untersuchungen zur Geschichte der altchristlichen Literatur 175; Berlin: Walter de Gruyter, 2017), with valuable contributions on Syriac topics.

5 The current vibrancy of the field can be seen in the work of the Comparative Oriental Manuscripts project at the University of Hamburg (http://www.aai.uni-hamburg.de/en/comst/ and the series Studies in 
encourage scholars to reconsider the form and function of the manuscript as archive, artifact, totem, instrument of orthodoxy, sign of power, library, culture, or literary persona. ${ }^{6}$

The need for such scholarship in Syriac studies is increasingly pressing. ${ }^{7}$ In a 2011 article, Sir Fergus Millar expressed surprise at the absence of recent work on even our earliest dated manuscript, British Library, Additional 12,150. "It seems extraordinary," he said, "that, as it seems, there has been no overall study of the codex as a physical object, nor any comparative study of the language of the six different translations contained in it." ${ }^{\prime 8}$ In fact, of the fifty-four earliest manuscripts, dated from 411-611, only a handful have received the kind of detailed study "as a physical object" that Millar calls for. ${ }^{9}$ Only recently has Ambrosiana MS. B. 21 Inf., the famous seventh century Old Testament Peshitta codex, received this

Manuscript Cultures, published by De Gruyter (https://www.degruyter.com/view/serial/43546).

6 For some recent examples see, Michael Friedrich and Cosima Schwarke, eds., One-Volume Libraries: Composite and Multiple-Text Manuscripts (Studies in Manuscript Cultures 9; Berlin: De Gruyter, 2016).

7 A valuable collection of recent studies on Syriac manuscripts can be found in, Françoise Briquel Chatonnet and Muriel Debié, eds., Manuscripta Syriaca. Des sources de première main (Cahiers d'études syriaques 4; Paris: Geuthner, 2015).

${ }^{8}$ Fergus Millar, Empire, Church and Society in the Late Roman Near East: Greeks, Jews, Syrians and Saracens (Collected Studies, 2004-2014) (Leuven: Peeters, 2015), 588. Reprint of Fergus Millar, "Greek and Syriac in Edessa: From Ephrem to Rabbula," Classica et Semitica 4 (2011): 99-113.

${ }^{9}$ For the list of the 54 dated manuscripts between 411 and 611 see, Sebastian P. Brock, "A Tentative Check List of Dated Syriac Manuscripts up to 1300," Hugoye: Journal of Syriac Studies 15 (2012): 21-48. For a study of Vatican Syriac 160, dated to 473, see Dina Boero, "The Context of Production of the Vatican Manuscript of the Syriac Life of Symeon the Stylite," Hugoye: Journal of Syriac Studies 18:2 (2015): 319-359. A detailed description of British Library Additional 14,542, dated to 509, is given in David G. K. Taylor, ed., The Syriac Versions of the De Spiritu Sancto by Basil of Caesarea (CSCO 576; Louven: Peeters, 1999), xi-xvii. For the Rabbula Codex, dated to 586, see, Massimo Bernabò, Il Tetravangelo di Rabbula: Firenze, Biblioteca Medicea Laurenziana, Plut. 1.56 : l'illustrazione del Nuovo Testamento nella Siria del 6. secolo (Roma: Edizioni di storia e letteratura, 2008). 
kind of attention, thanks to the excellent work of Philip Forness and Liv Ingeborg Lied, ${ }^{10}$ and this is just one of hundreds of significant early manuscripts deserving study. ${ }^{11} \mathrm{It}$ is clear from this pioneering work that our understanding of Syriac manuscript cultures increases significantly through deep studies of particular manuscripts, ${ }^{12}$ studies of scribal centers, ${ }^{13}$ as well as through comparative and longitudinal studies. ${ }^{14}$ Our

10 Philip Michael Forness, "Narrating History through the Bible in Late Antiquity: A Reading Community for the Syriac Peshitta Old Testament Manuscript in Milan (Ambrosian Library, B. 21 inf.)," Le Muséon 127:1-2 (2014): 41-76; and Liv Ingeborg Lied, "2 Baruch and the Syriac Codex Ambrosianus (7a1): Studying Old Testament Pseudepigrapha in Their Manuscript Context," Journal for the Study of the Pseudepigrapha 26:2 (2016): 67-107.

11 Another two hundred undated manuscripts in the British Library were assigned to the fifth through seventh centuries on paleographical grounds by William Wright.

12 For example, the two exemplary codicological studies by JosephMarie Sauget: "Reconstitution d'un manuscrit double originaire du Tūr 'Abdīn et actuellement depécé: Sbath 125 + Mingana Syriaque 88," Memorie della Reale Accademia Nazionale dei Lincei. Classe di Scienze morali, storiche e filologiche VIII 19:3 (1976): 357-439; and, Un cas très curieux de restauration de manuscrit: le Borgia syriaque 39. Étude codicologique et analyse du contenu (Studi e Testi 292; Città del Vaticano: Biblioteca Apostolica Vaticana, 1981).

${ }^{13}$ For example, Sebastian P. Brock, "Syriac Manuscripts Copied on the Black Mountain, near Antioch," in Lingua Restituta Orientalis: Festgabe für Julius Assfalg (ed. Regine Schulz and Manfred Görg; Wiesbaden: Otto Harrassowitz, 1990), 59-67; and idem., "Syriac on Sinai: the Main Connections," in EYKOLMLA: Studi miscellanei per il $75^{\circ}$ di Vincenzo Poggi S.J. (ed. Vincenzo Ruggieri and Luca Pieralli; Soveria Mannelli: Rubbettino, 2003), 103-117; and ibid., "Manuscripts Copied in Edessa," in Orientalia Christiana: Festschrift für Hubert Kaufhold zum 70. Geburtstag (ed. Peter Bruns and Heinz Otto Luthe; Wiesbaden: Harrassowitz Verlag, 2013), 109-128.

${ }^{14}$ For example, Marlia Mundell Mango, "Patrons and Scribes Indicated in Syriac Manuscripts, 411 to 800 AD," in Akten des XVI. Internationaler Byzantinistenkongress Wien, 4.-9. Oktober 1981 Jahrbuch der Österreichischen Byzantinistik 32.4. Vienna: Österreichischen Akademie der Wissenschaften, 1982) 3-12; idem., "The Production of Syriac Manuscripts, 400-700 AD," in Scritture, libri e testi nelle aree provinciali di Bisanzio: Atti del seminario di Erice (18-25 settembre 1988) (ed. Guglielmo Cavallo, Giuseppe de Gregorio, and Marilena Maniaci; Biblioteca del Centro per il collegamento degli studi medievali e umanistici nell'Universita 
most important source for understanding Syriac manuscript cultures is ${ }^{15}$ however, still the well-produced manuscript catalogue. ${ }^{16}$ Unfortunately, catalogues are frequently referred to, but rarely read. This may seem an odd observation. However, from the telegraphic, technical prose of the catalogues emerges a nuanced narrative of the creative principles that inform the construction of Syriac manuscripts, or, in other words, a poetics of Syriac manuscript cultures. ${ }^{17} \mathrm{I}$ aim to contribute to this emerging narrative by considering how the recent catalogue of the Library of Deir al-Surian by Sebastian Brock and Lucas Van Rompay increases our understanding of the poetics of Syriac manuscript cultures.

The Syriac library of Deir al-Surian is the most important collection of Syriac manuscripts surviving from antiquity. The collection was thought to be entirely dispersed among libraries in Barcelona, Dublin, Florence, London, Milan, New York, Paris, St. Petersburg, and the Vatican (see appendix for details).

di Perugia 5; Spoleto: Centro italiano di studi sull'alto Medioevo, 1991), 161-179; and Sebastian P. Brock, "Syriac Manuscripts of the 9th-10th Centuries from a Codicological Perspective," Semitica et Classica 8 (2015): 157-164.

15 On manuscript cultures see the important recent volume, Jörg Quenzer, Dmitry Bondarev, and Jan-Ulrich Sobisch, Manuscript Cultures: Mapping the Field (Studies in Manuscript Cultures 1; Berlin: De Gruyter, 2014).

${ }^{16}$ The most recent published guide to Syriac manuscripts catalogues is, Alain Desreumaux and Françoise Briquel-Chatonnet, Répertoire des bibliothèques et des catalogues de manuscrits syriaques (Paris: Éditions du Centre National de la Recherche Scientifique, 1991). A valuable introduction to Syriac manuscripts is found in, Françoise Briquel-Chatonnet, "Les manuscrits syriaques," in Nos sources. Arts et littérature syriaques (Sources syriaques 1; Antélias: Centre d'Études et de Recherches Orientales, 2005), 49-73. The first footnote of this introduction promises a Manuel de codicologie syriaque by Briqel-Chatonnet, Muriel Debié and Alain Desreumaux, which will be an important resource. For the time being we have the valuable Syriac chapters in, Alessandro Bausi, ed., Comparative Oriental Manuscript Studies: An Introduction (Hamburg: COMSt, 2015).

17 Amir Harrak, Catalogue of Syriac and Garshuni Manuscripts: Manuscripts Owned by the Iraqi Department of Antiquities and Heritage (CSCO 639; Subsidia 126; Leuven: Peeters, 2011), is an exceptionally readable catalogue. 
However, a significant portion of the manuscripts and fragments remained at the monastery. These were partially and provisionally described by Egyptian scholars in 1901 and 1951, and then became the object of renewed study in the mid-1990s by Van Rompay and Brock. The resulting catalogue is a magnificent work of scholarship, providing a history of the collection (xiii-xix), ${ }^{18}$ collection highlights (xix-xxi), brief handlists for manuscripts (3-4) and fragments (347-68), interesting and unusually rich descriptions of 48 codices, comprising 77 manuscript units (5-343), and 243 manuscript and 83 papyrus fragments (373-475), bibliography and indices (477-509), and an album of high-quality images (511-834). This beautifully produced catalogue contributes significantly to every aspect of our understanding of Syriac manuscript cultures. ${ }^{19}$ In this essay, I wish to expose some of the richness of this catalogue by focusing on the paratexts it records so thoroughly, particularly as they relate to scribes, readers and borrowers.

\section{SCRIBES}

As David Taylor reminds us, "much can be gained from considering the function and significance of manuscript paratexts." ${ }^{20}$ One function the paratexts serve is as a record of

18 Contains two minor errors: On the bottom of page xiv, for C 313 Inf., read B. 21 Inf. Ambrosiana MS. C 313 Inf. is, of course, the famous Syro-Hexaplar manuscript, which was, as Wright notes, another early acquisition from Deir al-Surian. In footnote 8 on the same page, for Vatican Syr. 110, read Vatican Syr. 112, where the colophon is found on $\mathrm{f}$. $1 \mathrm{r}$. This error is carried over from the chapter by Sebastian Brock cited in that note-see footnotes 30 and 38, though the reference he gives to Assemani's catalogue is correct in both cases.

19 At a time when even the best academic presses are publishing aesthetically inferior, perfect bound, print on demand books, it is a pleasure to work with such a well-made book, which, despite its size and the abundance of plates, is still very reasonably priced. The Peeters' publishing house is to be congratulated.

20 David G.K. Taylor, "The Psalm Headings in the West Syrian Tradition," in The Peshitta: Its Use in Literature and Liturgy. Papers Read at the 
the "life of texts and books," a record, according to Muriel Debié, that gives "voice to the people involved in copying, reading, buying, illustrating and binding the manuscripts." 21 Firstly, however, it is important to remember the "manus" in these manuscripts. The scribe is present in their "hand." The corollary is also true- the "hand" makes the scribe continually known, or present, to the reader. The scribe is an agent, an identity, a person, and the manuscript is not only the transmission of a text, but also of this identity, whether named in a colophon or not. ${ }^{22}$ Hatch's Album teaches us to think in periodized script types, and there certainly is meaningful diachronic variation in Syriac scribal hands. ${ }^{23}$ Yet there is also meaningful synchronic variation, revealing scribal individuality. The sixth-century hands of Deir al-Surian Syriac (DS) $1 \mathrm{~A}$ and B, for example, are both described by Van Rompay as "very regular and beautifully executed." 24 Yet, they each have distinctive features, distinctiveness that is found in the details. In the hand of DS 1A "Alaf has a light shoe; semkat is not connected to the left; the eye of taw may vary: it sometimes is fully open while in other cases it is nearly or fully closed. The

Third Peshitta Symposium (ed. Bas ter Haar Romeny; Leiden: Brill, 2006), 365378.

21 Muriel Debié, "Cataloguing in Many Ways: The Case Study of Charfet and e-Ktobe," in Manuscripta Syriaca. Des sources de première main (ed. Françoise Briquel Chatonnet and Muriel Debié; Cahiers d'études syriaques 4; Paris: Geuthner, 2015), 125-138, citing page 137.

${ }^{22}$ For an introduction to Syriac scribal culture see, "The Art of the Scribe," in The Heirs of the Ancient Aramaic Heritage (ed. Ewa BalickaWitakowski et al.; vol. 2 of The Hidden Pearl: The Syrian Orthodox Church and its Ancient Aramaic Heritage, ed. Sebastian P. Brock and David G.K. Taylor; Rome: Trans World Film Italia, 2001), 243-262.

23 William H. P. Hatch, An Album of Dated Syriac Manuscripts (Monumenta Palaeographica Vetera, 2nd series; Boston: American Academy of Arts and Sciences, 1946; repr., Piscataway: Gorgias Press, 2002, with a new Forward by Lucas Van Rompay). Cf. Catalogue, xxi-xxii, where the Brock and Van Rompay present a valuable "five-fold classification" schema that they developed "for the considerable variety of different scripts" found in the manuscripts and fragments.

${ }^{24}$ Catalogue, 5. 
two tails of mim are quite long." ${ }^{25}$ In the hand of DS 1B "the middle leg of he is quite long and points to the left; final unconnected nun starts well above the line, and its thin tail occasionally goes three of four letters back; the lower part of sàdè is quite prominent and sometimes continues under the two or three following letters; the eye of taw is open and usually quite big." 26 In these delicate and exemplary descriptions we find the individuality of the scribes. ${ }^{27}$ The catalogue is teaching us to see their individual presence, not simply to connect manuscripts, ${ }^{28}$ cluster scribes into schools, or create a more reliable periodization of script types, but ultimately to help us recognize the agency behind variation in texts and manuscripts. This is the agency of variants, corrections, anthologies and recension-the agency of the scribe as editor and active transmitter. ${ }^{29}$ Recognizing that this agentive transmission is the

25 Catalogue, 5.

${ }^{26}$ Catalogue, 7. See image on p. 518.

27 Cf. Lucas Van Rompay, "Syriac Paleography," in The Eerdmans Encyclopedia of Early Christian Art and Archeology (3 vols.; Grand Rapids, MI: Eerdmans, 2017) 2: 291. See also the important recent work on Syriac paleography by Ayda Kaplan, beginning with her, "La paléographie syriaque: Proposition d'une méthode d'expertise," in Manuscripta Syriaca. Des sources de première main (ed. F. Briquel Chatonnet and M. Debié; Cahiers d'études syriaques 4; Paris: Geuthner, 2015), 307-319.

28 The scribal hand of DS $2 \mathrm{~A}$ is connected with that of Florence, Biblioteca Medicea-Laurenziana, Plut. I.56, dated to 586, the famous Rabbula Gospels.

${ }^{29}$ Examples of agentive scribal action in the Syriac tradition are given in, Kristian S. Heal, "Five Kinds of Rewriting: Appropriation, Influence and the Manuscript History of early Syriac Literature," Journal of the Canadian Society of Syriac Studies 15 (2015): 51-65. The place of scribal agency in manuscript cultures is admirably accounted for in such classic works as, Bart Erhman, The Orthodox Corruption of Scripture: The Effect of Early Christological Controversies on the Text of the New Testament. Updated Edition. Oxford: Oxford University Press, 2011; and Kim Haines-Eitzen, Guardians of Letters: Literacy, Power, and the Transmitters of Early Christian Literature. Oxford: Oxford University Press, 2000. 
foundation of scribal culture puts the humanity back into paleography. ${ }^{30}$

The scribe also provides the form and structure of the codex, including the layout of the page, running headers, the codicos, or table of contents, titles, headings, assignment of authorship, beginnings and endings, and praise. ${ }^{31}$ Running headers often appear at regular intervals: in DS 1B, "on the fifth and the tenth folio of each quire." 32 In DS 2A "On the last folio of each quire." In-text headings, set off in red, can be rare in early scriptural manuscripts. British Library Add Ms 14425, the oldest copy of the Book of Genesis in Syriac (dated to 464 A.D.), has only one heading on $\mathrm{f}$. 19a to mark the opening of Genesis 22. It simply reads, "The Trial of Abraham." DS 4, a sixth-century copy of Kings, has headings at the beginning and end of the sections dealing with Elijah (1 Kings 16:29-2 Kings 2:18) and Elijah (2 Kings 2:19-13:21). ${ }^{33}$ Headings are relatively more frequent and effusive in the nine surviving folios of DS $1 \mathrm{~A}$ and DS 2B, both sixth century copies of the Books of Samuel.

${ }^{30}$ Of course, scribes also simply made errors, so not all textual variants are illustrative of agentive transmission.

31 The catalogue consistently gives clear and precise descriptions of quire composition, page size, writing area, line height, and paratextual elements. On page layout in early Syriac manuscripts see, Françoise BriquelChatonnet, "La mise en page dans les manuscrits syriaques d'après les anciens manuscrits," Manuscripta Orientalia: International Journal for Oriental Manuscript Research 9 (2003): 3-13; and Adya Kaplan, "The Shape of the Letters and the Dynamics of Composition in Syriac Manuscritps (Fifth to Tenth Century)," in Ruling the Script in the Middle Ages: Formal Aspects of Written Communication (ed. S. Barret, D. Stutzmann and G. Vogeler; Utrecht Studies in Medieval Literacy 35; Turnhout: Brepols, 2016), 379-398. More generally see, Marilena Maniaci, Construqione e gestione della pagina nel manoscritto bizantino (Cassino: Università degli Studi di Cassino, 2002).

32 Also DS 6B.

33 Catalogue, 19. 
The scribe speaks for himself only in the colophons. ${ }^{34}$ Words of praise flow anonymously from their pen, as in DS 6A, a sixth century Job manuscript, which concludes, "Praise to the Father and to the Son and to the Holy Spirit now and always and in eternity of eternities. Amen and Amen."35 Their own words are often brief and earnest. All we have from one of the scribes of the sixth century manuscript DS $6 \mathrm{~B}$, the Book of Daniel with Bel and the Dragon, and Thecla, is, "Remembered (be) all our Lord's saints here and everywhere. And on Yuhannan, who wrote, may there be mercy on the Day of Judgement. Yea and Amen."36 This scribe, who had maintained a regular and beautiful hand, and carefully identified the kingdoms and figures in Daniel in his section headings, simply sought mercy at the conclusion of this particular work.

The scribe of DS 10, a manuscript completed in Edessa during the month of October 510, is more effusive. We learn of the sitting Bishop, Mar Paula, the piety of the brothers who commissioned the manuscript ("they strove and acquired this treasure"), and hear the scribe's prayers for the owners of this splendid manuscript: "Grant them to be reading this book in purity and holiness, and may he hold them worthy of that holy utterance which says, 'Come, blessed ones of my Father, inherit the Kingdom which was prepared for you from before the foundation of the world' (Mt. 25:34); and may he cause them to recline at the table of his Kingdom; at the prayers of the holy Apostles and martyrs and confessors who have loved him. Amen and Amen." ${ }^{37}$ Here is a rare glimpse of the articulate, literate scribe at work. Note also the important (because rare) reference to "reading ... in purity and holiness."

${ }^{34}$ On the form and features of early Syriac colophons see, Sebastian P. Brock, "Fashions in Early Syriac Colophons," Hugoye: Journal of Syriac Studies 18:2 (2015): 361-377.

${ }_{35}$ Catalogue, 26. Cf. DS 6B f. 131v (Catalogue, 31);

${ }_{36}$ Catalogue, 31.

${ }^{37}$ Catalogue 50. 


\section{READERS}

Occasionally one encounters owners, readers, and even pilgrims in the paratexts. Erased or repeated colophons, declarations of ownership and purchase, marginal comments, or notes that memorialize visits to certain manuscripts are all evidence of the sociability of Syriac manuscripts. DS 1B, for example, is an interesting case because of the presence of textual intervention (three erasures that remove textual variation) and a series of early notes on $\mathrm{f}$. $114 \mathrm{rv}$ by La'azar the Abbot, the (original) sixth-century owner, whose deacon Toma, may have been responsible for the erasures when he "collated this book;" Shem'on the priest and abbott and his brother Sargis who "made" (rebound?) the manuscript in the early eighth century; and a reader's note by Severus written in $717 / 18$ recording an earthquake "at the daybreak of the nativity of Our Lord." 38 The record of the purchase of the manuscript by the Takritan brothers is found on $\mathrm{f} .11 \mathrm{r}$, as is a later owner's note placing "under the verdict" anyone who "borrows it [for] more than six months." 39 These notes reveal the movement of the text from commission to subsequent purchase. They show the manuscript as memorial, and indicate the sociality of the manuscript, and the need to control that sociality.

The scribe ends his work with the future reader in mind, even when a manuscript is written for a particular individual. In most cases the reader is addressed in the third person, but in some the fourth wall is broken and the reader is invoked directly. For example, the colophon on f. 206v of DS 14, a beautiful Masoretic manuscript written in the tenth or eleventh century, addresses these future readers directly: "A certain Matthew wrote this book, a sinner in need of God's mercy; it is he who is asking you, $\mathrm{O}$ reader who loves God and

38 Other notes recording historical events include DS 5 f. $1 \mathrm{r}$ (death of Hisham, Feb. 743);

${ }^{39}$ Catalogue, 8-9. See the Appendix to this essay for the bibliography on the Takritan brothers and Deir al-Surian. 
uprightness, to continually render prayer on his behalf, so that in your case you may fulfil and complete the apostolic law, whereas in the case of me who is the asker, I may be held worthy of mercy from God through your prayer, like the thief of the right hand; yea and amen." ${ }^{40}$ In a note earlier in the manuscript (f. 149r), the scribe, Mattai, similarly addresses the reader directly: "Be aware, O our brother (and) God-fearing reader who comes across this book that I expended a great deal of labour and care on it, having copied it complete from three manuscripts, and from the 'correction' of Theodosius, (who is) eloquent in Greek. For I copied it for myself and for my nephew who is adorned in his name MWSNY. But do you, who in (future) times come to acquire the ownership of this treasure, treat it with care and reverence out of love for Christ. The Old and New Testament was completed according to the recent 'correction' and the Peshitta at my hands, the sinner Mattai from the Monastery of the Cold River. Let everyone who reads pray for me."

Clearly some manuscripts were commissioned specifically with a broader readership in mind. For example, Shem'on the Priest and Sargis the Deacon, who commissioned the copy of the Book of Exodus that comprises DS 1B, prayed that (f. $114 \mathrm{v}$ ) "every believer and orthodox who wants to read (in it) and benefit from it pray for them." ${ }^{.11}$ Likewise, a note added to DS 6A by the Takritan brothers asks that "everyone who reads in [the manuscript] pray for them that they may find mercy at the judgement along with the robber at the right hand." ${ }^{42} \mathrm{On}$ folio 1r of Vatican Syraic 112, one of the manuscripts acquired by Moshe of Nisibis, we read that the manuscripts were acquired for the glory of God "and for the benefit of those who read them." ${ }^{43}$ Other notes acknowledge that manuscripts were borrowed in order to be read (see below). A later owner's

${ }^{40}$ Catalogue, 71. The thief on the right hand is also evoked in DS $30 \mathrm{f}$. 74r (Catalogue, 223).

${ }^{41}$ Catalogue, 9.

42 Catalogue, 28.

${ }^{43}$ Catalogue, xiv (read 112 for 110 in footnote 8). 
note in DS 37, the Fenquitho for Easter, notes that manuscript was bought "in order to read and to study ( 2 msua) in it for the profit of their soul." "44 The tenth century scribe of DS 31B even notes at the end of a letter of Jacob of Serug to Mar Giwargi that the letter now passes "through him to all the scribes who in the future will chance on this letter and read (it)." 45 The same scribe left a note for a specific reader, "Read, Mar Abbot, and pray for my humbleness." Van Rompay notes that, "it is just possible that the abbot addressed here was Mushe of Nisibis."46 Most notes, however, record the responses of readers to the manuscript, or memorialize their presence in the manuscript. ${ }^{47}$

These readers who followed also left their marks. A nice example of a reader's note is found in Vatican Syriac 117 f. $2 \mathrm{v}$. It simply states that George the Lesser ( $\mathrm{ri}_{5}$ (a) touched this manuscript on 1787 AG/1476 AD. Why leave such a note? Probably because the manuscript is huge - 555 folios measuring $48 * 32 \mathrm{~cm}$, written in three dense columnsand already a couple of hundred years old when George encountered it. Such codices, like the Church of the Holy Sepulchre, are marvelous and renowned monuments, certainly worth visiting when passing through the monastery that owned them. And if you got the chance to see such a manuscript you would want to leave your mark, as Sargis the Monk from Hah, who left an inscription on both St. Mark's Monastery Ms. 25 and upon one of the engaged columns in front of the western

${ }^{44}$ Catalogue, 270.

45 F. 81r; Catalogue, 233.

46 Catalogue, 234.

47 These notes belong to the same cultural domain as the inscriptions left by visitors on the monastery walls. For the types of inscriptions with examples see, Lucas Van Rompay, "Deir al-Surian: Miscellaneous Reflections," Essays in Christian Art and Culture in the Middle East 3 (2000): 80-87. 
entrance to the Church of the Holy Sepulchre during a visit to Jerusalem in either 1490 or $1502 .^{48}$

Readers' notes vary in detail. The fullest give the author's name, origin and date, and an invocation, as in DS 3B f. 25r, where at the end of the manuscript, we find this reader's note: "That sinner, Abraham the Easterner, of Beth Sbirino, read in this book, in the year 1804 of the Greeks [= AD 1492/3]. Let whoever reads (this) pray for him." ${ }^{, 49}$ Interestingly, just the year before, an anonymous Easterner from the same village left a note "in a big hand" on the bottom half DS 9 f. 30v, a blank space at the end of an extract of Josephus' Jewish Wars, which reads, "An evil sinner, an Easterner, from Tur ('Abdin), from Beth Sbirino, came across this holy book of histories (in) the year 1803 of the Greeks. And to God praise!"50 Another reader from Tur 'Abdin left a note in DS 10, the Gospel codex dated to $510 \mathrm{AD}$, which prays, "In the name of the living God. Remember, O Lord, your sinful servant Yeshu', insignificant and useless among monks, from the region of Tur 'Abdin, from the village called Basbirino, the castra which is on the boundary of the holy and priestly monastery of Qartmin." 51 Thus, the notes expose patterns of pilgrimage and travel, both temporal and spatial.

48 Sebastian P. Brock, Haim Goldfus and Aryeh Kofsky, "The Syriac Inscriptions at the Entrance to the Holy Sepulchre, Jerusalem," ARAM 1819 (2006-7): 415-438, inscription discussed on 417-18. On the manuscript notes by East Syriac pilgrims to Jerusalem in this period see, Sebastian P. Brock, "East Syriac Pilgrims to Jerusalem in the Early Ottoman Period," ARAM 18-19 (2006-2007): 189-201.

${ }^{49}$ Catalogue, 15.

${ }^{50}$ Catalogue, 44; Cf. Catalogue, 16.

51 Catalogue, 51. Cf. DS 22 f. 155v, reader's note from AD 1068 ("I beg

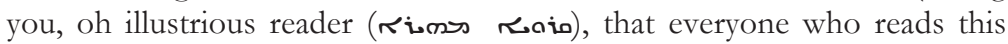
couple of lines would pray and say: 'God, He who is the companion of the oppressed, provide for Shem'on the sinner forgiveness of (his) sins as well as a good [.?.] for every Christian who enters this place. And may everyone

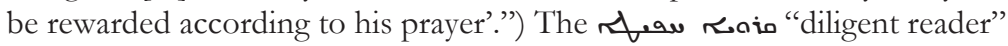
is addressed in a note in British Library Add. 12,138 f. 311v. 
What is it that drew these travelers to these manuscripts? Were these pilgrims looking for "the therapy of distance" that Peter Brown talks about in his Cult of the Saints? ${ }^{52}$ Michael Cronin, writing of acts of translation, adapts Brown's metaphor in a useful way. He observed that, "When pilgrims go on a journey, the principal discovery is not destination but distance. The spiritual value lies as much, if not more, in the wandering as in the arrival." Thus, the presence of the manuscript evokes the therapeutic distance of the past and future. To adapt Cronin's reflection on monuments (drawing from Debray), "The [manuscript] links the past, present and future. It reminds those who are of those who were before and indicates a future time when they will no longer be, but others will be there in their place, contemplating the same [manuscript]." ${ }^{33}$ The manuscript now encourages those followers to pray for these pioneers who had gone before, further cementing the ties between past and future.

The note on DS 6A f. $2 \mathrm{r}$ goes even further, praying both for those who read to pray, as well as for the efficacy of their prayers: "May God bless the convent and everyone who lives in it for eternity. Amen. And may everyone who reads in this book say: May God have mercy on Athanasius the sinner and recluse. And may the Lord hear your prayer for eternity. Amen." This Athanasius is in earnest, and repeats his request in two further notes at the end of the manuscript. In the first of these he also asks to be remembered in the prayers of his brothers and sisters in Christ who might read this manuscript. In the second he asks, "may everyone who reads (this) pray for him." ${ }^{54}$ In another case, DS 6B f. 64r, the reader's comment is anonymous, but no less earnest, "My brothers, pray for me for our Lord's sake, I beg you." ${ }^{\prime \prime 5}$

52 Peter Brown, The Cult of the Saints: Its Rise and Function in Latin Christianity (Chicago: Chicago University Press, 1981), 87.

53 Michael Cronin, Translation and Globalization (London: Routledge, 2003), 9 .

${ }^{54}$ Catalogue, 28.

${ }^{55}$ Catalogue, 32. 
According to an owner's note in DS 19, a sixth or seventh century collection of sermons on Romans by John Chrysostom, one does not just read a manuscript, one

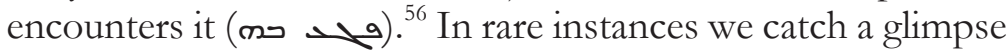
of the aesthetic reaction of those encountering the library or a particularly striking manuscript. In British Library Add. 14,699 f. 1r, for example, Thomas of Mardin, clearly a bibliophile, left a record of his visit to the Monastery library in 1624: "I entered the Monastery of the Virgin in the Desert of Sketis, and I saw the books without number, arranged without any order. I began lovingly to dust them, and I counted them: they came to four hundred and three. Also I arranged them in the tower." ${ }^{, 57}$ In DS 14 f. 2r, we find a delightfully appreciative reaction, both aesthetic and scholarly, from John of M'arre (a village near Nisibis) made in 1511/12 to this obviously striking Masoretic manuscript: ${ }^{58}$ "And when I was present in our Monastery of the Syrians and I saw this book, which is extremely beautiful (ivar 1 . I ), I read in it and had great comfort from it; and I saw that its contents and points were precise and very accurate." ${ }^{, 59}$

In most cases readers leave no trace in a manuscripts, or just signs of wear. ${ }^{60}$ In others, the trace is slight, ${ }^{61}$ or pedantic,

${ }^{56}$ Catalogue, 99. The note is found on f. 145r: "This book belongs to the priest Severus [ ... ] and to Yeshu, his son, who acquired it for the benefit of their souls and of all (those) who encounter it. But whoever borrows it in order to read in it or to write from it, and does not return it to its owners, God will say to him on the Day of Judgment: 'I do not know

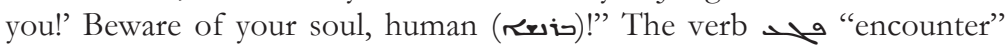
appears frequently in notes and colophons in British Library manuscripts.

${ }^{57}$ Catalogue, xv.

${ }^{58}$ Images found in Catalogue, 543-44.

${ }^{59}$ Catalogue, 72. Cf. DS 12 f. $1 \mathrm{r}$ for another note from this John of M'arre (Catalogue, 57-58).

${ }^{60}$ As in DS 30, Catalogue, 220 ("The many finger stains indicate that the manuscript was much read.”)

${ }^{61}$ A note preserved inside the leather binding of DS 13 simply states, "Zachariah the sinful monk scribbled (this)." The use of the verb $t^{\text {io }}$ "scribbled" is interesting (Catalogue, 61). 
such as in DS 1A, where a "later hand occasionally added Greek vowels on proper names," $"$ perhaps under the influence of the exacting scholarship of the Syriac Masoretic tradition, or as a sign that the text was becoming increasingly strange, or distant. ${ }^{63}$ We also find instances where a reader adds a note to correct attribution, or indicate that certain leaves have become displaced. ${ }^{64}$ In some instances, such as DS 29, we find that a reader has, "overwritten certain words that had become difficult to read and added a few marginal notes." the margin provided space for drawings, some fine, others rather rudimentary. ${ }^{66}$ Seven birds adorn the margins of DS6A, one of which, considered by Van Rompay to be "especially beautiful," ${ }^{67}$ is reproduced on page 525 of the catalogue.

\section{BORROWERS}

Owner's notes indicate that manuscripts were read and borrowed, and that owners looked to divine aid and warnings to control the flow of books. A note on $\mathrm{f}$. $1 \mathrm{r}$ of DS 4 is typical: "This book belongs to the Holy Monastery. Anyone who takes it in order to read in it and does not bring it (back) to its owners is under the word of God until he brings it back to its owners." ${ }^{\prime 68}$ Six months seems to have been the standard lending period, as the note in DS 6A, f. 63r indicates: "Anyone who borrows this Book of Job in order to read in it or for whatever reason, he does not have authority from God to keep it with him for more than six months. ${ }^{\circ 9}$ For some books, however, a stricter usage policy was sometimes imposed, as with DS 4, f. $119 \mathrm{v}$ : "This book belongs to the Monastery of the Syrians of

${ }^{62}$ Catalogue, 5.

63 Addition of Greek vowels also found in DS 6 (Job, $6^{\text {th }} \mathrm{c}$.); east Syriac vowels added by an early reader in DS 10 (Catalogue, 52).

${ }^{64}$ E.g., DS 29 f. 56v and 65v (Catalogue, 215-16).

${ }^{65}$ Catalogue, 212.

${ }^{66}$ DS6A f. 2r, "Rude drawings and a note"(Catalogue, 28).

67 Catalogue, 29.

${ }^{68}$ Catalogue, 20.

${ }^{69}$ Catalogue, 28-29; cf. DS 6B f. 64r (Catalogue, 32). 
the desert. Let there be an anathema on anyone who removes it from it. Amen. Praise to our Lord." As the note mentioned above indicates, books were borrowed "in order to read in it or for whatever reason." We are left wondering about other uses in the partly damaged note added to DS $4 \mathrm{f}$. 120, which states that "[Anyone who takes it ...] either to read in it or to [...] from it." The fuller note surviving in DS $10 \mathrm{f}$. 154r completes and extends the couplet: "Everyone who borrows this book, to read it, or to copy from it, or whatever reason, so as to be benefitted by it ..." ${ }^{, 70}$ Other reasons might presumably include collation of a work.

Despite the emphasis on books being returned, manuscripts still went missing. The note on f. 120r of DS4 states that whoever "does not [return] it to its owner, he is under the word of God until he returns it." The warning phrase ,madur rmbrats heud also appears in the note on $\mathrm{f} .1 \mathrm{r}$ of the same manuscript. Other notes recognize the variety of ways that a manuscript could go missing and seek to legislate against them specifically. DS 6A suggests that some readers would simply hide a book that they didn't want to give back: "Everyone who reads in it [...] and would hide it ( محدק , حلar), he should know that he has transgressed the word of God and (his) commandment." ${ }^{, 71}$ The Monastery note in DS 9 aims to close any possible loop-hole in the library-use-only policy, with a concomitant ratcheting up on the promised punishments for offenders: " "This book belongs to the Holy

${ }^{70}$ Catalogue, 51.

71 Catalogue, 28.

72 For other similarly detail prohibitions see, Vatican Syriac 112, f.1r ("no one is authorized to abscond with a single one of them, or to delete this memorandum, or to remove, cut out or take them away from this monastery."); DS 28 1v, which is identical to BL Add. 17,141, f. 110v ("This book belongs to Ishaq, son of Abraham, son of Dinara, from Tagrit, who purchased it for his own benefit. But everyone who takes it, to read in it or to copy from it or for any other reason, and does not return it to its owner, it should be known (to him) that he is under the leprosy of Gehazi and the suffocation of Judas the traitor. And may all the curses that are described in the holy scriptures come over him, and may heaven above him become 
Monastery of the Bearer of God of the Syrians in the desert. Whoever removes it from there in the manner of a robber, or withholds it, or appropriates it to himself, or erases this note, or rubs (it) out or cuts (it) out, (he) will inherit the shaking of

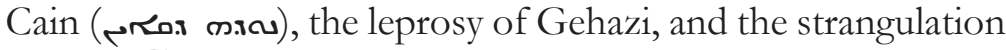
of Judas, ${ }^{73}$ and he will be reckoned among the spoilers of the sanctuary." "74 The owner's note on $\mathrm{f}$. 1 of Deir al-Surian in DS 28 adds to the list of ways a manuscript could be misappropriated or defaced by including the provision, "or orders another person (to do so)., ${ }^{75}$

Seemly, only the fear of prolonged divine judgement or anathema were enough to ensure that most books were

bronze and the earth below him iron, and may his work become a perforated pouch (! ?), and the spear that transfixed Henanya transfix him and destroy his life from the earth. And may his portion be with with the violators of the sanctuary of the Lord. Beware, oh miserable one, and don't be negligent! For the one who is negligent with regard to (this) word will be destroyed by it; and the one who fears the commandment will be saved forever. Amen." Catalogue, 209-10);

${ }^{73}$ Cain in also invoked in a note on f. 1r of DS 12 (Catalogue, 57-58); Judas is also invoked in DS 27 f. 94r (together with "Hanan and Caiaphas, and with Nestorius and with Arius, and with Leo, and with Theodoret, and with Barsauma the Persian, and with those whose fire will never been extinguished and whose [... ] will not die."); and DS $28 \mathrm{f} .1 \mathrm{v}$ (see note 72 above).

${ }^{74}$ Catalogue, 46. On "the Shaking of Cain," see Philoxenus, First Letter to Beth Gaugal, where Philoxenus deploys the same phrase in a theological anathema: "He who does not believe that He Who, as man, was apprehended by the Jews and led to the death of the Cross, is the Same Who, as God, in the power of his divinity caused creatures to tremble

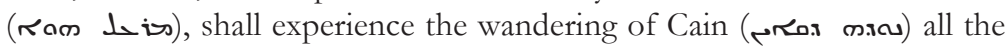
days of his life." Arthur A. Vaschalde, Three Letters to Philoxenus, Bishop of Mabbogh (485-519) (Rome: Tipografia della R. Academia del Lincei, 1902), $113, * 156$. Note how Vaschalde adopts a traditional rendering of r.s. Jessie Payne Smith prefers "Unrest" in the Compendious Syriac Dictionary, s.v. מחז. On Judas in the Syriac tradition, including the association with Gehazi see, Carl Griffin, "Vessel of Wrath: Judas Iscariot in Cyrillona and Early Syriac Tradition," in Literature, Rhetoric, and Exegesis in Syriac Verse (ed. Jeffery T. Wickes and Kristian S. Heal; Studia Patristica LXXVII; Leuven: Peeters, forthcoming).

75 This leaf is a later addition to this codex. Catalogue, 210. 
returned. ${ }^{76}$ Once a book was acquired by Deir al-Surian the warnings intensified (DS 4, f. 119v): "Let there be an anathema (siv) on anyone who removes it from [the monastery of the Syrians]."77 Anathemas were even renewed by later ecclesiastical authorities, such as by the metropolitan of Jerusalem, who visited the monastery in $1516,{ }^{78}$ or visitors, such as John of M'arre who visited the monastery in $1511 / 12$. $^{79}$

Erasure was akin to theft. ${ }^{80}$ We find pervasive evidence for owners or donators who were also eager to see that their names were not erased, invoking divine powers to enforce their ownership claims or donation record. A note added by the Takritan brothers to DS 4 states that "anyone who erases their [ownership] record from this book will be anathema from the Father and the Son and the Holy Spirit." Another note from the Takritan brothers in DS $1 \mathrm{f} .11 \mathrm{r}$, states that "anyone who erases their name from this book, may his name by erased from the Book of Life." Curiously, the owner mentioned in a later note on the same page of DS 1 suffered this fate. No new name is added. The rest of the note simply remains as a generic warning to the potential borrower. In DS $6 \mathrm{~B}$ f. $64 \mathrm{r}$ we find both concerns articulated in a warning from the Monastery: "If

${ }^{76}$ On anathemas in Deir al-Surian manuscripts see, Sebastian P. Brock, "Abbot Mushe of Nisibis, Collector of Syriac Manuscripts," in Gli studi orientalistici in Ambrosiana nella cornice del IV centenario, 1609-2009: primo dies academicus, 8-10 novembre 2010 (Ed. Carmela Baffioni, Rosa Bianca Finazzi, Anna Passoni Dell'Acqua, and Emidio Vergani; Orientalia Ambrosiana 1; Milan: Biblioteca Ambrosiana, 2012), 15-32, esp. 26-28.

77 Catalogue, 20.

${ }^{78}$ Catalogue, xv.

${ }^{79}$ Catalogue, 58. Both were asked to add anathema by the same abbot, Bishop Severus.

80 Erasure was made in response to a variety of factors. See, for example, Michael Penn's exemplary work historicizing certain patterns of erasure: Michael Philip Penn, "Piety and the Pumice Stone: Erasure in Syriac Manuscripts," Studia Patristica 45 (2010): 197-201; idem., "Monks, Manuscripts, and Muslims: Syriac Textual Changes in Reaction to the Rise of Islam," Hugoye: Journal of Syriac Studies 12:2 (2009): 235-257; idem., "Moving beyond the Palimpsest: Erasure in Syriac Manuscripts," Journal of Early Christian Studies 18:2 (2010): 261-303. 
(someone) daringly erases (rula viss) this note or keeps (the book) with him, he is under the verdict." ${ }^{\prime 1}$ The significant number of owners' names that were erased, or renewed by subsequent owners, show that this was a real concern, making it difficult to differentiate between the legitimate and illegitimate transfer of ownership and movement of manuscripts.

Thanks to the new data provided in this catalogue, we now know more about the single most significant pre-modern movement of Deir al-Surian manuscripts. A note on DS 30 f. 230r records the fact that the Patriarch Michael the Great "snatched" or "sent and took" not just a handful, as previously thought, but one hundred "choice books in good condition

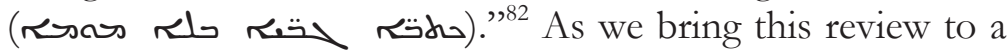
close, it is worth reflecting for a moment on the significance of these two adjectival modifiers. They seem to indicate both an aesthetic and an intellectual motivation for the selection of manuscripts. But can we discern more there? Can we see this same pair of motivations at work in the acquisition of manuscripts both for and from the library? I am struck by William Wright's obvious frustration, for example, that "the

${ }^{81}$ Catalogue, 32. "Daringly," wiss, or "rashly" appears otherwise only on the previous note at the end of DS 6A f. 63r (Catalogue, 29), suggesting the same author.

82 Cf. Catalogue, xv-xvi, 227-38. Cf. Van Rompay, "Deir al-Surian: Miscellaneous Reflections," 85, for a first notice of colophons showing that Michael the Great borrowed manuscripts from Deir al-Surian. The fate of these books differs in the two notes that mention the removal. In the first, "They took a hundred books, but sent back to us only thirty." Blessings were promised those who returned the books: "Anyone who takes the trouble for God's sake and helps to bring back those books which are in the Monastery of Mor Barșaumo, may God pardon him, Amen." In a later note we are told that, "And let everyone know that Patriarch Mor Michael sent and took from this monastery a hundred choice books in good condition (lit. without blemish). We sent a messenger concerning them and he brought eighty of them back, while the others remained in the Monastery of Mor Barșa[umo].” Catalogue, 228 (the notes, possibly anachronistically, suggest that a fire consumed the Patriarch's library because he retained these manuscripts). 
Trustees of the British Museum should have failed to secure the whole of the Nitrian collection of Syriac MSS." In particular, that "M. Pacho kept back four fine MSS (among them the Ecclesiastical History of Eusebius, dated to A.D. 462), which now adorn the shelves of the Imperial Public Library at St. Petersburg." ${ }^{83}$ There is a hunger, a visceral acquisitiveness that is activated by these "choice books in good condition," and it is not unreasonable to question its nobility. We perhaps even need to rethink the motives and aesthetics of Moshe's acquisitions. Once we move beyond simple gratitude, how should we characterize the acquisitiveness of Moshe of Nisibis? What do his acquisitions tell us about him as a scholar, an antiquarian, or a bibliophile? ${ }^{84}$ These are questions that need answering within his cultural and intellectual context. We also need to ask what the manuscripts he acquired represented to those who sold or gave them to this wandering abbot.

The idea of "choice books in good condition" also makes us think about the aesthetics of the modern, European acquisition of the Deir al-Surian library. Certainly, the fact that there are no joins with BAV manuscripts is significant, suggesting that the Assemanis were particularly attracted to intact codices, "choice books in good condition." The experience of the British Library was different. The aesthetics of acquisition had changed-texts were now even more important than codices. Every loose leaf was potentially valuable, and librarians were willing to take great pains to reassemble manuscripts in their quest for new texts. ${ }^{85}$ Thus, the renaissance of Syriac studies in the nineteenth century was sparked not simply by the British Library's acquisition of the

83 William Wright, "Syriac Manuscripts at St. Petersburg, etc.," The Journal of Sacred Literature and Biblical Record, New Series, X:20 (1867): 46162.

84 Sebastian Brock discusses the possibility of "Mushe's growing antiquarian interests" as a motive for acquisition in, "Abbot Mushe of Nisibis, Collector of Syriac Manuscripts," 28-29.

${ }^{85}$ Cf. William Cureton, "British Museum-MSS. from the Egyptian Monasteries," Quarterly Review 77: 153 (December, 1845): 39-69. 
Syriac manuscripts held by the Monastery of the Syrians in the Egyptian desert, ${ }^{86}$ but by a certain mode of acquisition that corresponded to the sophisticated greediness of the new age. The manuscripts catalogued by Brock and Van Rompay represent, to some extent, the systemic inertia resisting such approaches. Despite the repeated efforts to purchase all of the manuscripts from the Monastery of the Syrians some stubbornly remained, as an apposite metaphor of the monks who cared and who still care for them.

\section{CONCLUSIONS}

In order to demonstrate the richness of the paratextual material published in this catalogue, I have risked flattening a complex collection of data points gathered from diverse geographical locations during a period of over a thousand years. Nonetheless, some observations can be made about the three types of material presented. Scribal activity was clearly spiritual work, freighted with far-reaching salvific hopes. The formulaic nature of scribal colophons should not detract from their sincerity, or depreciate their value as evidence for Christian culture. Scribes often described the completion of their work as a ship coming into harbor after a long voyage. ${ }^{87}$ Yet, the completed codex also left the scriptorium like a ship setting sail, and, as long as it survived, the work it performed was combined with the hopes of its scribe, owners and readers, not simply that they might be memorialized, but so that they might be the beneficiaries of the faith and prayers of generations. Erasure and removal of names and notes takes on even greater significance when viewed from the vantage of such hopes. Moreover, we should take seriously the implications of

${ }^{86}$ Félix Jean Baptiste Nève, De la renaissance des études syriaques. Lettre à M. Le directeur des annales de philosophie chrétienne (Paris: Benjamin Duprat, 1854); and the earlier article by Georg Heinrich Bernstein, "Syrische Studien," Zeitschrift der Deutschen Morgenländischen Gesellschaft 3 (1849): 385 428; 4 (1850): 198-223 305-322.

87 Sebastian P. Brock, "The Scribe Reaches Harbour," Byzantinisches Forschungen 21 (1995): 195-202. 
removing these manuscripts from a community of faith, and the significance of restoring them, even virtually.

The publication of this catalogue marks the end of a threehundred-year European project to acquire and describe the Syriac library of Deir al-Surian. It is a modern catalogue, valuing both text and paratexts, authors and scribes, literary cultures and manuscript cultures. It is also the first catalogue of this library not predicated on acquisition. It is, of course, an act of appropriation, inasmuch as it seeks to obtain a scholarly image of the collection, but also an act of appreciation, and an act of recognition of distance. Thus, the catalogue is more than a scholarly tool, more than a bricolage of fragments of manuscript cultures - it is also a memory of manuscript encounters. And we are the readers who follow, repeating and connecting with this collection, both through and with that encounter.

All this is really to say that the significance of the catalogue produced by Sebastian Brock and Lucas Van Rompay cannot be overstated. It is a monumental achievement by two of the finest Syriac scholars of our time, indeed of modern Syriac studies. The mastery of literature, history, culture, and manuscripts that it displays it remarkable. The sensitivity, delicacy, accuracy and thoroughness of their descriptions and annotations is exemplary. It is clearly a labor of love and devotion, and as such this catalogue stands as a magnificent and fitting tribute to the "Abbots, Librarians and Monks of Deir al-Surian past and present," to whom it is dedicated.

The rich and nuanced portrait that Brock and Van Rompay's catalogue gives us of Syriac manuscript cultures is an invitation to probe further, and to ask new questions, both of specific manuscripts and of the library as a whole. What do the manuscripts tell us about the literary and intellectual culture of a given period, and temporal and geographic variations in that culture? What kind of works are our earliest manuscripts performing? What functions are scribal invocations playing in scribal culture and the spirituality of learned monasteries? Do the manuscripts indicate a scribe's desire to craft a self- 
conscious literary persona ${ }^{88}$ What does the permanence of the codex suggested by scribal and readers' notes suggest about manuscripts as artifacts?

To answer such questions, however, all of the Deir alSurian manuscripts need to be catalogued to the standard modeled by Brock and Van Rompay. This would facilitate a virtual reconstruction of the library; a project that should be actively pursued at the level of manuscript description through the Paris-based digital humanities project, e-ktobe. Once the cataloguing data for the entire library has been added to ektobe, this incredibly valuable resource could provide fuller scope for intertextual and inter-manuscript analysis, knowledge networks, scribal practices, and the study of manuscript cultures. ${ }^{89}$ Such a resource could be complemented by a comprehensive volume of colophons and notes found in the Deir al-Surian manuscripts, with complete editions and annotated translations, a dictionary of the scribal lexicon, and larger projects. Together, these tools would be invaluable to a much-needed comprehensive history of the library. This recitation of research possibilities and next steps is simply an extended acknowledgement of the vital and foundational role played by codicology in general, and of this catalogue in particular.

${ }^{88} \mathrm{I}$ borrow this language from Andrew Jacobs, Epiphanius of Cyprus: $A$ Cultural Biography of Late Antiquity (Oakland: University of California Press, 2016), 18.

89 e-ktobe Manuscripts syriaque: http://www.mss-syriaques.org/. For an introduction to the project see, Debié, "Cataloguing in Many Ways." 


\section{APPENDIX:}

The Monastery and Syriac Manuscripts of Deir al-Surian: A Topical Bibliography.

\section{Surveys of Scholarship}

Van Rompay, Lucas. "Deir al-Surian: Miscellaneous Reflections," Essays in Christian Art and Culture in the Middle East 3 (2000): 80-87.

2. History of the Monastery

Cody, Aelred. "Dayr al-Suryan, History." Pages 876-879 in The Coptic Encyclopedia. Edited by Aziz S. Atiya. New York: MacMillan, 1991.

den Heijer, Johannes. "Relations between Copts and Syrians in the Light of Recent Discoveries at Dayr as-Suryân." Pages 929-944 in Coptic Studies on the Threshold of a New Millennium, I-II: Proceedings of the Seventh International Congress of Coptic Studies, Leiden, 27 August-2 September 2000. Edited by Mat Immerzeel and Jacques van der Vliet. Orientalia Lovaniensia Analecta 133. Leuven: Peeters, 2004.

Evelyn-White, Hugh Gerard. The Monasteries of the Wadi ' Natruin, Part 2: The History of the Monasteries of Nitria and of Scetis. Publications of the Metropolitan Museum of Art 7. New York: The Metropolitan Museum of Art, 1932.

Innemée, Karel C., and Lucas van Rompay. "La présence des Syriens dans le Wadi al-Natrun (Égypte). À propos des découvertes récentes de peintures et de textes muraux dans l'Église de la Vierge du Couvent des Syriens." Parole de l'Orient 23 (1998): 167-202.

Leroy, Jules. "Un témoignage inédit sur l'état du monastère des Syriens au Wadi 'n Natrûn au début du XVIème siècle." Bulletin de l'Institut Français d'Archéologie Orientale 65 (1967): $1-23$. 
Leroy, Jules. "Compléments à l'histoire des couvents du Ouadi Natroun d'Evelyn White." Bulletin de l'Institut Français d'Archéologie Orientale 70 (1971): 225-233.

Monneret de Villard, Ugo. Les églises du monastère des Syriens au Wầî en-Natrûn. Milano: Tipografia di San Giuseppe, 1928.

Van Rompay, Lucas. "Deir al-Surian: Miscellaneous Reflections." Essays in Christian Art and Culture in the Middle East 3 (2000): 80-87.

Van Rompay, Lucas, and Andrea B. Schmidt. "Takritans in the Egyptian Desert: The Monastery of the Syrians in the Ninth Century." Journal of the Canadian Society for Syriac Studies 1 (2001): 41-60.

Van Rompay, Lucas. "L'histoire du Couvent des Syriens (Wadi al-Natrun, Égypte) à la lumière des colophons de la Bibliothèque nationale de France. Avec un appendice sur le MS. BnF syr. 199." Pages 343-371 in Manuscripta Syriaca: Des sources de première main. Edited by F. Briquel Chatonnet and Muriel Debié. Cahiers d'études syriaques 4. Paris: Geuthner, 2015.

Van Rompay, Lucas. "Le Couvent des Syriens en Égypte aux 15ème et 16ème siècles: L'apport des colophons syriaques de la Bibliothèque nationale de France." Parole de l'Orient 41 (2015): 549-572.

\section{Coptic Context and Coptic-Syriac Interactions ${ }^{90}$}

den Heijer, Johannes. "Relations between Copts and Syrians in the Light of Recent Discoveries at Dayr as-Suryân.” Pages

90 Scholarship to the end of the $20^{\text {th }}$ century assumes that the monastery was under Coptic control (c. 530 to 710) until it was purchased by Takritan merchants, when it became a Syriac monastery (710-1637), followed by its return to Coptic control. Later scholarship indicates that Syrian monks from Takrit first established a Syrian presence in the monastery in the early $9^{\text {th }}$ century, and that there was the continued presence of Copts and Coptic culture throughout the history of the monastery. 
929-944 in Coptic Studies on the Threshold of a New Millennium, I-II: Proceedings of the Seventh International Congress of Coptic Studies, Leiden, 27 August-2 September 2000. Edited by Mat Immerzeel and Jacques van der Vliet, Orientalia Lovaniensia Analecta 133. Leuven: Peeters, 2004.

Fiey, Jean-Maurice. "Coptes et Syriaques, contacts et échanges." Studia Orientalia Christiana, Collectanea 15 (19721973): 295-365.

Immerzeel, Mat. "The Crowned Altar: The Stuccoes of Deir al-Surian and Their Historical Background." Essays on Christian Art and Culture in the Middle East 3 (2000): 40-62.

Immerzeel, Mat. "A Play of Light and Shadow: The Stuccoes of Dayr al-Suryan and their Historical Context." Coptica 3 (2004): 104-129.

Immerzeel, Mat. "The Stuccoes of Deir al-Surian: A waqf of the Takritans in Fustat?," Pages 1303-1320 in Coptic Studies on the Threshold of a New Millennium, I-II: Proceedings of the Seventh International Congress of Coptic Studies, Leiden, 27 August-2 September 2000. Edited by Mat Immerzeel and Jacques van der Vliet, Orientalia Lovaniensia Analecta 133. Leuven: Peeters, 2004.

Immerzeel, Mat. "Playing with Light and Shadow: The Stuccoes of Deir al-Surian and Their Historical Context." Eastern Christian Art 5 (2008): 59-74.

Innemée, Karel C., and Lucas van Rompay. "La présence des Syriens dans le Wadi al-Natrun (Égypte). À propos des découvertes récentes de peintures et de textes muraux dans l'Église de la Vierge du Couvent des Syriens." Parole de l'Orient 23 (1998): 167-202.

Van Rompay, Lucas. "Deir al-Surian (Egypt): Its Wallpaintings, Wall-texts, and Manuscripts. II. Syriac Inscriptions in Deir al-Surian: Some Reflections on Their Writers and Readers." Hugoye: Journal of Syriac Studies 2: 2 (1999): 189-202. 
Van Rompay, Lucas. "Deir al-Surian: Miscellaneous Reflections." Essays in Christian Art and Culture in the Middle East 3 (2000): 80-87.

Van Rompay, Lucas, and Andrea B. Schmidt. "Takritans in the Egyptian Desert: The Monastery of the Syrians in the Ninth Century." Journal of the Canadian Society for Syriac Studies 1 (2001): 41-60.

4. Collection History

a. Surveys and General History

Brock, Sebastian P., and Lucas Van Rompay. Catalogue of the Syriac Manuscripts and Fragments in the Library of Deir al-Surian, Wadi al-Natrun (Egypt). Orientalia Lovaniensia Analecta 227. Leuven: Peeters, 2014. [p. XIV-XVIII offer a brief outline of the "Growth" and "Migration" of the collection].

el-Suriany, Bigouel, and Lucas Van Rompay. "Syriac Papyrus Fragments Recently Discovered in Deir al-Surian (Egypt)." Hugoye: Journal of Syriac Studies 4 (2001): 93-101.

el-Suriany, Bigouel. "The Manuscript Collection of Deir alSurian: Its Survival into the Third Millennium.” Pages 281294 in Coptic Studies on the Threshold of a New Millennium, III: Proceedings of the Seventh International Congress of Coptic Studies, Leiden, 27 August-2 September 2000. Edited by Mat Immerzeel and Jacques van der Vliet, Orientalia Lovaniensia Analecta 133. Leuven: Peeters, 2004.

Evelyn-White, Hugh Gerard. The Monasteries of the Wadi 'n Natruin, Part 2: The History of the Monasteries of Nitria and of Scetis. Publications of the Metropolitan Museum of Art 7. New York: The Metropolitan Museum of Art, 1932. Pages 439-458 contain, "Excursus: the Library of the Syrian Monastery." 
b. Early Period (before Moses of Nisibis)

Van Rompay, Lucas, and Andrea B. Schmidt. "Takritans in the Egyptian Desert: The Monastery of the Syrians in the Ninth Century." Journal of the Canadian Society for Syriac Studies 1 (2001): 41-60.

c. Mushe of Nisibis (c. 900-950)

Blanchard, Monica Joan. "Moses of Nisibis (fl. 906-943) and the Library of Deir Suriani." Pages 13-24 in Studies in the Christian East in Memory of Mirrit Boutros Ghali. Edited by L.S.B. MacCoull. Publications of the Society for Coptic Archaeology, North America 1. Washington, D.C.: Society for Coptic Archaeology, 1995.

Brock, Sebastian P. "Without Mushê of Nisibis, Where Would We Be? Some Reflections on the Transmission of Syriac Literature." Journal of Eastern Christian Studies 56: 1-4 (2004): $15-24$.

Brock, Sebastian P. "Abbot Mushe of Nisibis, Collector of Syriac Manuscripts." Pages 15-32 in Gli studi orientalistici in Ambrosiana nella cornice del IV centenario, 1609-2009: primo dies academicus, 8-10 novembre 2010. Edited by Carmela Baffioni, Rosa Bianca Finazzi, Anna Passoni Dell'Acqua, and Emidio Vergani. Orientalia Ambrosiana 1. Milan: Biblioteca Ambrosiana, 2012.

Hunt, Lucy-Anne. "Stuccowork at the Monastery of the Syrians in the Wādī Natrūn: Iraqi-Egyptian Artistic Contact in the "Abbasid Period." Pages 93-128 in Christians at the Heart of Islamic Rule: Church Life and Scholarship in 'Abbasid Iraq. Edited by David Richard Thomas. The History of Christian-Muslim Relations 1. Leiden: Brill, 2003. ${ }^{91}$

Leroy, Jules. "Moïse de Nisibe." Pages 457-470 in Symposium Syriacum, 1972: célebré dans les jours 26-31 octobre 1972 à l'Institut Pontifical Oriental de Rome. Edited by Ignatius Ortiz

91 Treats attribution of stuccowork to Mushe. 
de Urbina. Orientalia Christiana Analecta 197. Rome: Pontificium Institutum Orientalium Studiorum, 1974.

Innemée, Karel C. "The Doors of Deir al-Surian Commissioned by Moses of Nisibis: Some Observations on the Occasion of Their Restoration." Pages 193-214 in Syriac Encounters: Papers from the Sixth North American Syriac Symposium, Duke University, 26-29 June 2011. Edited by Maria E. Doerfler, Emanuel Fiano, and Kyle Richard Smith. Eastern Christian Studies 20. Leuven: Peeters, 2015.

Martin, Matthew J. "Athanasiana Syriaca and the Library of Dayr al-Suryan." Ancient Near Eastern Studies 40 (2003): 225234.

Snelders, Bas. Identity and Christian-Muslim Interaction: Medieval Art of the Syrian Orthodox from the Mosul Area. Orientalia Lovaniensia Analecta 198. Louvain: Peeters, 2010.

d. Later Acquisitions (950 onwards) ${ }^{92}$

Martin, Matthew J. "Athanasiana Syriaca and the Library of Dayr al-Suryan." Ancient Near Eastern Studies 40 (2003): 225234.

Van Rompay, Lucas. "A Precious Gift to Deir al-Surian (AD 1211): Ms. Vat. Syr. 13.” Pages 735-749 in Malphono w-Rabo d-Malphone: Studies in Honor of Sebastian P. Brock. Edited by George Anton Kiraz. Gorgias Eastern Christian Studies 3. Piscataway, NJ: Gorgias Press, 2008.

Harrak, Amir. "Bacchus, son of Mattay. A Master Calligrapher in the Mongol Period." Pages 107-22 in From Ugarit to Nabataea: Studies in Honor of J.F. Healey. Edited by George A. Kiraz and Z. Al-Salameen. Piscataway, NJ: Gorgias Press, 2012. ${ }^{93}$

92 Brock \& Van Rompay, Catalogue, xiv-xv describes several manuscripts copied at the Monastery, including one by Mushe of Nisibis, as well as later donations to the Library.

93 On British Library Or. 8729, purchased by Robert Curzon. 


\section{Catalogue and Manuscript Descriptions}

Brock, Sebastian P., and Lucas Van Rompay. Catalogue of the Syriac Manuscripts and Fragments in the Library of Deir al-Surian, Wadi al-Natrun (Egypt). Orientalia Lovaniensia Analecta 227. Leuven: Peeters, 2014.

Kamil, Murad. Catalogue of the Syrian Manuscripts Newly Found in the Monastery of St. Mary Deipara in the Nitrian Desert. Trans. Piet Dirksen. n.d. (composed in Arabic in c. 1951).

Van Rompay, Lucas. "A Precious Gift to Deir al-Surian (AD 1211): Ms. Vat. Syr. 13.” Pages 735-749 in Malphono w-Rabo d-Malphone: Studies in Honor of Sebastian P. Brock. Edited by George Anton Kiraz. Gorgias Eastern Christian Studies 3. Piscataway, NJ: Gorgias Press, 2008.

6. Dispersal of Manuscripts

Brock, Sebastian P., and Lucas van Rompay. Catalogue of the Syriac Manuscripts and Fragments in the Library of Deir al-Surian, Wadi al-Natrun (Egypt). Orientalia Lovaniensia Analecta 227. Leuven: Peeters, 2014. Pages $x v$-xviii give an overview; specific pages given below.

a. Monastery of Barsaumo (borrowed by Michael the Great) Brock \& Van Rompay, Catalogue, xv-xvi.

Van Rompay, Lucas. "Deir al-Surian: Miscellaneous Reflections," Essays in Christian Art and Culture in the Middle East 3 (2000): 80-87, esp. 85.

b. St. Mark's, Jerusalem

Brock \& Van Rompay. Catalogue, xvi.

c. Milan, Ambrosiana

MS. B. 21 Inf. \& MS. C 313 Inf.

Brock \& Van Rompay. Catalogue, xvi.

MS. C 313 Inf. = Syro Hexaplar: Pasini, Cesare, Emidio Vergani, and Philippe Luisier. "Per la storia della siro- 
esaplare Ambrosiana (alla luce delle annotazioni siriache e copta recentemente rinvenute sul codice)." Orientalia Christiana Periodica 71 (2005): 21-58.

B. 21 Inf. = OT Peshitta 7a1: Vergani, Emidio. "Il colofone della Syro-pšittā ambrosiana." Pages 287-312 in Gli studi orientalistici in Ambrosiana nella cornice del IV centenario, 16092009: primo dies academicus, 8-10 novembre 2010. Edited by Carmela Baffioni, Rosa Bianca Finazzi, Anna Passoni Dell'Acqua, and Emidio Vergani. Orientalia Ambrosiana 1. Milano: Biblioteca Ambrosiana, 2012.

d. Paris, $B N F$

Syriaque MSS. 27, 56, 69, 170, 199.

Brock and Van Rompay. Catalogue, xvi n. 25. ${ }^{94}$

Omont, Henri. Missions archéologiques françaises en Orient aux XVIIe et XVIIIe siècles. 2 pts. Paris: Imprimerie Nationale, 1902. ${ }^{95}$

Van Rompay, Lucas. "L'histoire du Couvent des Syriens (Wadi al-Natrun, Égypte) à la lumière des colophons de la Bibliothèque nationale de France. Avec un appendice sur le MS. BnF syr. 199.” Pages 343-371 in Manuscripta Syriaca: Des sources de première main. Edited by F. Briquel Chatonnet and Muriel Debié. Cahiers d'études syriaques 4. Paris: Geuthner, 2015.

e. Vatican Apostolic Library ${ }^{96}$

Vatican Syriac 5, 13, 18, ${ }^{97}$ 25, 26, 92, 93, 100, 103, 104, 105, 106, 107, 108, 109, 110, 111, 112, 113, 114, 115, 116, 117, 120, 122, $123,124,125,135,136,137,138,139,140,141,142,143,145$,

${ }^{94}$ Lists mss from DS that ended up in Paris, surmising that they were acquired during the second half of the $17^{\text {th }} \mathrm{C}$.

95 Describes desired Syriac manuscripts (I.37-40), and acquired Syriac manuscripts (II. 951, 967, 979-80, 989-90).

${ }^{96} \mathrm{I}$ am preparing a new catalogue of these manuscripts.

${ }^{97}$ Levi della Vida, Ricerche, 419 [via. Mushe of Mardin, 16th C]. 
158, 160, 161, 162, 163, 189, 198, 251, 252, 253, 254, 255, 256, 367, Barb. Or. 2.98

Brock and Van Rompay. Catalogue, xvii.

Assemani, Joseph Simonius. Bibliotheca orientalis Clementino-

Vaticana. 3 vols. Roma: Typis Sacrae Congregationis de Propaganda Fide, 1719-1728.9

Assemani, Stefanus Evodius, and Joseph Simonius Assemani. Bibliothecæ Apostolicæ Vaticanæ codicum manuscriptorum catalogus. Part I, tom. 2 \& 3. Roma: Ex typographia linguarum orientalium, 1758-1759.

Levi Della Vida, M. Giorgio. Ricerche sulla formaz̧ione del più antico fondo dei manoscritti orientali della Biblioteca Vaticana. Studi e Testi 92. Città del Vaticano: Biblioteca Apostolica Vaticana, 1939.

\section{f. Florence, Biblioteca Medicea-Laurenziana}

Oriental 30, 58, 298..$^{100}$

Brock and Van Rompay, Catalogue, xvii n. 28. ${ }^{101}$

Borbone, Pier Giorgio. "Un progetto di bibbia poliglotta di Giovanni Battista Raimondi e il MS. Firenze, Biblioteca

${ }^{98}$ Delio Vania Proverbio suggests that the Pentaglot Psalter (Barb. Or. 2) was written at Deir al-Surian in "Alle Origini delle collezioni librarie orientali," in Storia Della Biblioteca Apostolica Vaticana. Volume 1: Le origini della biblioteca Vaticana tra umanesimo e rinascimento (1447-1543) (ed. Antonio Manfredi; Città del Vaticano: Biblioteca Apostolica Vaticana, 2010), 46785 , spec. 480.

99 Thirty-four Nitrian manuscripts listed in Vol. 1, 561-72; Cf. Henri Hyvernat, "Vatican Syriac MSS.: Old and New Press-Marks," The Catholic University Bulletin 9 (1903): 94-104.

${ }^{100}$ I am grateful to Prof. Pier Giorgio Borbone (University of Pisa) for providing this list of manuscripts, the relevant bibliography and additional valuable information about the Deir al-Surian manuscripts acquired by the Biblioteca Medicea-Laurenziana.

101 The evidence of the existing manuscripts does not seem to support the claim that, "Other manuscripts brought back from Deir al-Surian at this time [early $18^{\text {th }} \mathrm{C}$ ] went to the Biblioteca Medicea-Laurenziana in Florence." 
Medicea Laurenziana, Or. 58 (9a1).” Pages 191-228 in Bibbia e Corano: edirioni e ricezioni. Edited by Carmela Baffioni, Anna Passoni Dell'Acqua, Rosa Bianca Finazzi, and Emidio Vergani. Orientalia Ambrosiana 5. Rome: Bulzoni, 2016, esp. p. 211-13.

\section{g. British Library}

BL Or. 8729-8732 derive from the 1837 purchase of Robert Curzon; ${ }^{102}$ BL Add. 12,133-12,181 derive from the 1841 purchase by Henry Tattam; BL Add. 14,425-14,739 derive from the 1841-2 purchase of over 300 manuscripts by Henry Tattam, received in 1843; ${ }^{103}$ BL Add. 17,102-17,274 derive from the 1845 purchase of over 150 manuscripts by Auguste Pacho, who was commissioned by William Cureton; BL Add. 18,812-18,821 derive from the Pacho 1845 purchase, but were only sold to the BL in 1851.

Brock \& Van Rompay. Catalogue, xvii.

Cureton, William. "British Museum-MSS. from the Egyptian Monasteries." Quarterly Review 77: 153 (December, 1845): 39-69 [21-37 in US edition].

Cureton, William, ed. The Festal Letters of Athanasius, Discovered in an Ancient Syriac Version. London: Society for the Publication of Oriental Texts, $1848 .^{104}$

102 Cf. Robert Curzon, Visits to Monasteries in the Levant, Curzon, Catalogue; Wright, Catalogue, III, x-xi.

103 These spans, taken from Wright's catalogue, are slightly at variance with a note on the end paper of BL Add. 14,425: "The series of Syriac MSS extending from No. 14,425 to No. 14,741 inclusive, formed a portion of the collection preserved in the monastery of St. Mary Deipara, in the desert of Nitria or Scete, about 70 miles from Cairo, and were obtained thence by the agency of the Revd. H. Tattam in 1841-42. They were received in March 1843. Another portion of the same collection was purchased of the Revd. H. Tattam in 1841 and are the Add. MSS. 12,134-12,191. T.M."

104 Preface contains a description of the acquisition of the third portion of the British Library purchase. This was reprinted with notes in, James Farwell Coakley, An Ancient Colophon: A Memoir by William Cureton. Oxford: Jericho Press, 1999. 
Wright, William. Catalogue of Syriac Manuscripts in the British Museum, Acquired since the Year 1838. 3 Parts. London: Trustees of the British Museum, 1870-1872. ${ }^{105}$

h. St. Petersburg, National Library of Russia

Syriac New Series MSS. 1-4 ${ }^{106}$

Dorn, Bernhard. "Ueber vier von der Kaiserlichen öffentlichen Bibliothek zu St. Petersburg im J. 1852 erworbene syrische Handschriften.” Mélanges Asiatiques tires du Bulletin Historico-philologique de l'Académie Impériale des Scienees de St. Pétersbourg II.2 (14-26 October, 1853): 195-210.

Wright, William. "Syriac Manuscripts at St. Petersburg, etc." The Journal of Sacred Literature and Biblical Record, New Series, X: 20 (1867): 461-62.

Goussen, H. "Über die syrischen Handscriften in Leningrad (Petersburg)." Oriens Christianus 1 (1927): 169-173, New Series no. 1-4 described on 170.

\section{i. Berlin State Library}

Ms. Orient Quarto 528

Wright, William. "Discovery of Additional Fragments of the Curetonian Gospels." The Academy 2 (October 1, 1871): 468. ${ }^{107}$

105 Detailed history of the collection given in preface to part III.

106 Sold to the Library in St. Petersburg in 1852 by Auguste Pacho from his 1845 purchase. Grigory Kessel gives the following summary of the Russian catalogue by Nina Viktorovna Pigulevskaja: I. First and Second Samuel. 6th C. 78ff (=NS 2); XV. Pauline Epistles. 5-6th C. 112 ff (=NS 3); XXIV. Eusebius, Ecclesiastical History. 462 AD. $123 \mathrm{ff}$ (=NS 1); XLVIII. Lives of Saints. 6th C. $142 \mathrm{ff}$ (=NS 4).

107 This appears to be the first published notice of this manuscript: "Sir-It is much to be regretted that the Trustees of the British Museum should have failed to secure the whole of the Nitrian collection of Syriac MSS. This comes of trusting to the honesty of Arabs and Greeks. M. Pacho kept back four fine MSS (among them the Ecclesiastical History of Eusebius, dated to A.D. 462), which now adorn the shelves of the Imperial Public 
Sachau, Eduard. Verzeichniss der syrischen Handschriften der Königlichen Bibliothek zu Berlin. 2 vols. Berlin: A. Asher \& Co, 1899: 16-18.

j. Dublin, Chester Beatty Library

Chester Beatty 709 (olim MK 31 bis)

Brock \& Van Rompay. Catalogue, xix. ${ }^{108}$

Leloir, Louis. Saint Éphrem: Commentaire de l'Évangile Concordant, Texte Syriaque (Manuscrit Chester Beatty 709) Folios Additionnels. Leuven: Peeters, $1990{ }^{109}$

Peterson, William. Tatian's Diatessaron: Its Creation, Dissemination, Significance, and History in Scholarship. Leiden: Brill, 1994: 314-18.

k. Barcelona

P. Palau Rib. 2 (olim MK 31 bis; single leaf)

Brock \& Van Rompay. Catalogue, xix. ${ }^{110}$

Valdivieso, Pedro Ortiz. "Un neuvo fragment siriaco del commentario de San Efrén al Diatessaron (P. Palau Rib. 2)." Studia Papyrologica 5 (1966): 7-17.

Library at St. Petersburg. But there seem to be still more MSS form the same collection at Cairo or Alexandria. No less than thirty or forty volumes were offered by letter to the librarians of the Bibliothèque Nationale, shortly before the commencement of the siege of Paris by the Germans; and last year the famous Egyptologist, Dr. Brugsch, now residing in Egypt, purchased one, which has found a resting-place in the Royal Library at Berlin. This is a copy of the Gospels, made up of portions of several MSS, among which are three leaves of the Curetonian Gospels (Brit. Mus. Add. 14,451; see my Catalogue, part i. p. 73, no. cxix.). Professor Roediger of Berlin has made a careful copy of these leaves, and intends to have them printed this autumn for the use of Biblical students."

108 Timeline and extent of acquisition.

109 Pages v-x provide a history of acquisitions.

110 Timeline and extent of acquisition. 
Peterson, William. Tatian's Diatessaron: Its Creation, Dissemination, Significance, and History in Scholarship. Leiden: Brill, 1994: 318-19.

l. New York Public Library

Brock, Sebastian P. “The Transmission of Ephrem's madrashe in the Syriac Liturgical Tradition." Studia Patristica 33 (1997): 490-505. ${ }^{111}$

\section{Inscriptions $^{112}$}

Jenner, Konrad Dirk, and Lucas van Rompay. "New Syriac Texts on the Walls of the al-'Adra Church of Dayr alSuryân.” Mitteilungen zur christlichen Archäologie 4 (1998): 96103.

Martin, Matthew J. "A Syriac Inscription from Deir Al-Surian." Hugoye: Journal of Syriac Studies 5: 2 (2002): 237-242.

Van Rompay, Lucas. "Deir al-Surian (Egypt): Its Wallpaintings, Wall-texts, and Manuscripts. II. Syriac Inscriptions in Deir al-Surian: Some Reflections on Their Writers and Readers." Hugoye: Journal of Syriac Studies 2: 2 (1999): 189-202.

Van Rompay, Lucas. "Deir al-Surian: Miscellaneous Reflections." Essays in Christian Art and Culture in the Middle East 3 (2000): 80-87.

Van Rompay, Lucas, and Andrea B. Schmidt. "A New Syriac Inscription in Deir al-Surian (Egypt)." Hugoye: Journal of Syriac Studies 4: 1 (2001): 109-114.

111 Page 491 n. 2, refers to fragments "from the Syrian Monastery in the Nitrian Desert."

112 In addition to monumental inscriptions, Van Rompay identifies four kinds of wall texts/inscriptions: 1. First person visitors; 2. Third person visitors; 3. Obituaries; 4. Official Notices. See, Van Rompay, Lucas, "Deir al-Surian: Miscellaneous Reflections," Essays in Christian Art and Culture in the Middle East 3 [2000]: 81-82. 
Van Rompay, Lucas. "Deir al-Surian (Egypt): New Discoveries of 2001-2002. II. Syriac Texts." Hugoye: Journal of Syriac Studies 5: 2 (2002): 255-263.

8. Art \& Architecture

Hunt, Lucy-Anne. "Eternal Light and Life: A ThirteenthCentury Icon from the Monastery of the Syrians, Egypt, and the Jerusalem Pascal Liturgy." Jahrbuch der österreichischen Byzantinistik 43 (1993): 349-366.

Hunt, Lucy-Anne. "The Newly Discovered Wallpainting of the Annunciation at Dayr al-Suryān: Its Twelfth Century Date and Imagery of Incense." Cahiers archéologiques 43 (1995): 147-152.

Hunt, Lucy-Anne. "Stuccowork at the Monastery of the Syrians in the Wādī Natrūn: Iraqi-Egyptian Artistic Contact in the "Abbasid Period," Pages 93-128 in Christians at the Heart of Islamic Rule: Church Life and Scholarship in 'Abbasid Iraq. Edited by David Richard Thomas. The History of Christian-Muslim Relations 1. Leiden: Brill, 2003.

Immerzeel, Mat. "The Crowned Altar: The Stuccoes of Deir al-Surian and Their Historical Background." Essays on Christian Art and Culture in the Middle East 3 (2000): 40-62.

Immerzeel, Mat. "A Play of Light and Shadow: The Stuccoes of Dayr al-Suryan and their Historical Context." Coptica 3 (2004): 104-129.

Immerzeel, Mat. "The Stuccoes of Deir al-Surian: A waqf of the Takritans in Fustat?," Pages 1303-1320 in Coptic Studies on the Threshold of a New Millennium, I-II: Proceedings of the Seventh International Congress of Coptic Studies, Leiden, 27 August-2 September 2000. Edited by Mat Immerzeel and Jacques van der Vliet. Orientalia Lovaniensia Analecta 133. Leuven: Peeters, 2004. 
Immerzeel, Mat. "Playing with Light and Shadow: The Stuccoes of Deir al-Surian and Their Historical Context." Eastern Christian Art 5 (2008): 59-74.

Immerzeel, Mat. "Medieval Syrian Orthodox Church Decoration: Deir al-Surian and Deir Mar Musa," Pages 223-238 in The Syriac Renaissance. Edited by Herman G.B. Teule, Carmen Fotescu Tauwinkl, Bas ter Haar Romeny, and Jan van Ginkel. Eastern Christian Studies 9. Leuven: Peeters, 2010.

Innemée, Karel C., and Lucas Van Rompay. "La présence des Syriens dans le Wadi al-Natrun (Égypte). À propos des découvertes récentes de peintures et de textes muraux dans l'Église de la Vierge du Couvent des Syriens." Parole de l'Orient 23 (1998): 167-202.

Innemée, Karel C., Peter Grossmann, Konrad Dirk Jenner, and Lucas Van Rompay. "New Discoveries in the al-'Adra Church of Dayr as-Suryan in the Wadi al-Natrun." Mitteilungen zur christlichen Archäologie 4 (1998): 79-103.

Innemée, Karel C. "New Wall-Paintings." Mitteilungen zur christlichen Archäologie 4 (1998): 79-90.

Innemée, Karel C. "Recent Discoveries of Wall-Paintings in Deir Al-Surian." Hugoye: Journal of Syriac Studies 1: 2 (1998): 288-304.

Innemée, Karel C. “The Iconographical Program of Paintings in the Church of al-'Adra in Deir al-Sourian: Some Preliminary Observations." Pages 143-153 in Themelia. Spätantike und koptologische Studien Peter Grossmann zum 65. Geburtstag. Edited by Krause, Martin and Schaten, Sofia. Sprachen und Kulturen des christlichen Orients 3. Wiesbaden: Ludwig Reichert, 1998.

Innemée, Karel C. "Deir al-Surian (Egypt): Its Wall-paintings, Wall-texts, and Manuscripts. I. The Wall-paintings of Deir al-Surian: New Discoveries of 1999." Hugoye: Journal of Syriac Studies 2: 2 (1999): 167-188. 
Innemée, Karel C. "Deir al-Surian (Egypt): Conservation Work of Autumn 2000.” Hugoye: Journal of Syriac Studies 4: 2 (2001): 259-268.

Innemée, Karel C. "Deir al-Surian (Egypt): New Discoveries of 2001-2002. I. Wall Paintings." Hugoye: Journal of Syriac Studies 5: 2 (2002): 245-254.

Innemée, Karel C. "A Newly Discovered Mural Painting in Deir al-Surian." Eastern Christian Art 1 (2004): 61-66.

Innemée, Karel C. "A Newly Discovered Painting of the Epiphany in Deir Al-Surian.” Hugoye: Journal of Syriac Studies 14: 1 (2011): 63-85.

Innemée, Karel, Grzegorz C. Ochała, and Lucas Van Rompay. "A Memorial for Abbot Maqari of Deir al-Surian (Egypt): Wall Paintings and Inscriptions in the Church of the Virgin Discovered in 2014." Hugoye: Journal of Syriac Studies 18: 1 (2015): 147-190.

Innemée, Karel C. "The Doors of Deir al-Surian Commissioned by Moses of Nisibis: Some Observations on the Occasion of Their Restoration." Pages 193-214 in Syriac Encounters: Papers from the Sixth North American Syriac Symposium, Duke University, 26-29 June 2011. Edited by Maria E. Doerfler, Emanuel Fiano, and Kyle Richard Smith. Eastern Christian Studies 20. Leuven: Peeters, 2015.

Leroy, Jules. "Le décor de l'église du Couvent des Syriens au Ouady Natroun (Égypte)." Cahiers archéologiques 23 (1974): 151-167.

Leroy, Jules. "Dix années de recherches sur les peintures murales des monastères coptes de Haute et Basse-Egypte." Comptes-rendus des séances de l'Académie des Inscriptions et BellesLettres, Paris (1976): 570-586.

Leroy, Jules. La peinture murale chez les Coptes, II: Les peintures des couvents du Ouadi Natroun. Mémoires publiés par les membres de l'Institut français d'archéologie orientale du 
Caire 101. Cairo: Institut Français d'Archéologie Orientale, 1984.

Monneret de Villard, Ugo. Les églises du monastère des Syriens au Wâdî en-Natrûn. Milano: Tipografia di San Giuseppe, 1928.

Parandowska, Ewa. "Results of the Recent Restoration Campaigns (1995-2000) at Dayr el-Sourian," Coptica 3 (2004): 130-140.

Skálová, Zuzana. "St. John the Baptist in Dayr al-Suryan, in the Wadi Natrun: A Crusader Era Deesis Icon from the Byzantine Periphery Re-vivified Using the "Mobile Icon Restoration Unit” 2000-2010.” Byzantinoslavica 1-2 (2014): 350-369.

Snelders, Bas, and Mat Immerzeel. "The Thirteenth Century Flabellum from Deir al-Surian in the Musée Royal de Mariemont (Morlanwelz, Belgium)," Eastern Christian Art 1 (2004): 113-139.

Snelders, Bas. Identity and Christian-Muslim Interaction: Medieval Art of the Syrian Orthodox from the Mosul Area. Orientalia Lovaniensia Analecta 198. Louvain: Peeters, 2010.

Snelders, Bas. "The Relationship between Christian And Islamic Art: West Syrian Christians in the Mosul Area (Twelfth-Thirteenth Century). A Preliminary Note." Pages 239-264 in The Syriac Renaissance. Edited by Herman G.B. Teule, Carmen Fotescu Tauwinkl, Bas ter Haar Romeny, and Jan van Ginkel. Eastern Christian Studies 9. Leuven: Peeters, 2010.

Sobczynski, Elizabeth. "Deir al-Surian (Egypt): Its Wallpaintings, Wall-texts, and Manuscripts. III. The Conservation of Manuscripts in the Library of Deir alSurian: First Notes." Hugoye: Journal of Syriac Studies 2: 2 (1999): 203-207. 
Catalogues and the Poetics of Syriac Manuscript Cultures 417

Strzygowski, Josef. "Der Schmuck der älteren el-Hadrakirche im syrischen Kloster der sketischen Wüste." Oriens Christianus 1 (1901): 356-372.

Van Moorsel, Paul. "La grande annonciation de Deir es Sourian." Bulletin de l'Institut Français d'Archéologie Orientale 95 (1995): 517-537.

Van Loon, Gertude J.M. "Abraham, Isaac, and Jacob in Paradise in Coptic Wall Painting." Visual Resources 19.1 (2003): 67-79. 
